\title{
CORRESPONDENCE
}

\begin{abstract}
Apology
Most unfortunately, there was dropped from the proof of "The Pottery of Pecos" a statement which was included in the manuscript, acknowledging my deep indebtedness to Mr. F. G. Hawley of Miami, Arizona, for chemical analyses of glazes, made by him at my request. In the same lost paragraph acknowledgment was also made to Dr. Sigvald Linné of the Royal Ethnographic Museum of Stockholm, who also arranged to have analyses made for me in Sweden.
\end{abstract}

\section{A. V. KIDDER}

\section{Mountain Sheep Effigies}

During the summer of 1935 , while the author was a resident of Prescott, Arizona, as Curator of the Smoki Public Museum, the remains of what had once been a large walled compound of prehistoric times were excavated.

The location of the compound was but an approximate two miles from the center of the city of Prescott, and within the northern border of the fenced area known as the Fair Grounds, or Rodeo Field. About one-third of the ruined structure remained when excavation began. The rock and accumulated debris had been, during a period of forty years, a source of filling material for bridge approaches, house foundations, rock walls and well linings. The credit for preserving what remained of the compound until careful excavation could be made is due to Miss Grace Sparkes, Secretary of the Yavapai Chamber of Commerce, who influenced the withdrawal of a tractor and steam-shovel then at work levelling the remaining walls of the compound, and to the Smoki Public Museum for aid in excavation.

Perhaps it would be well to mention briefly the nature of the compound as it was revealed through the excavation. A large wall of cyclopean construction, twenty-four inches thick on the average, seventy-eight by fifty-six feet in length and breath dimensions, composed the original rock-wall structure. What the original height of the walls had been would be a conjecture, but seems reasonably to assume they were sufficiently high to afford protection in case of attack. The highest portion uncovered in the north section of the wall, was four and one-half feet. On the south, east and west sides only the wall outlines appeared; these were from six to sixteen inches high. No cross walls were uncovered on the original level within the compound. These compound walls in the direction of greatest length were approximately thirty degrees west and east of true north and south, respectively.

At the northern end and within the main walls, two walls at right angles to the former and of later masonry construction were encountered with foundations some thirty inches above the compound wall base. The rocks used in these secondary walls seemed to have been laid up in a well-mixed clay mortar and in 